\title{
Political Institutions and Macroeconomic Factors as Determinants of Credit Risk in South Africa
}

\author{
S. Zhou, D.D Tewari \\ Department of Economics, University of Zululand, Kwadlangezwa, South Africa \\ sheuedu@gmail.com, TewariD@unizulu.ac.za
}

\begin{abstract}
This study analyses the effects of political institutions and macroeconomic factors on credit risk in South Africa using quarterly data between 1998 and 2016. The study uses the ARDL approach to cointegration and reports on both long-run and short-run influences of credit risk. In the long-run political institutions and gold prices are found to positively impact credit risk whereas Gross domestic product has a negative influence on credit risk. In the short-run however political institutions have a negative influence on credit risk. Further, the study confirms the recent country risk downgrades by rating agencies, S \& P, Moody and Fitch. Policies that grow the economy and are consistent with the government's long-term strategy needs to be followed to improve investor and lender confidence.
\end{abstract}

Keywords: Credit risk, political risk, credit rating, cointegration

\section{Introduction}

Credit risk has become an important issue in today's economies as it determines the flow of funds to meet production needs. With a huge reliance on bank credit, South African firms could find it difficult to compete at the global or regional level if the cost of debt spirals. On the other hand, the government of South Africa has been reeling under a huge stock of debt, increasingly growing as the country continues to face unprecedented trade deficits (Ayadi and Ayadi, 2008). The credit risk downgrades experienced recently ${ }^{1}$ need to be analyzed in the context of the long-term relationship between political institutions and credit risk in the country. We ask the question whether political institutions matter for credit risk management in South Africa over both the short and long term. By so doing we contribute to the already established literature on the determinants of credit risk and proffer some policy options for the South African government. In debt markets, credit rating agencies play an important role by reducing search costs, lowering the incidence of moral hazard (Chang et al., 2017). During the past two decades rating agencies have become more popular, seemingly pointing out the bad apples from investment grade debt instruments. The South African government has not been spared by these referees, with several downgrades being assigned to the debt-burdened country as a result of several inconsistent decisions by the South African government. However, the long-term effects of such institutional factors on credit risk have not been documented. In this study we sought to establish to what extent these institutional factors are important in determining credit risk. Our results also seek to refute or validate recent public outcries over rating downgrades by credit rating agencies, Fitch, S\&P and Moody's.

\section{Literature Review}

Credit risk is a measure of the probability of default on the principal and interest components of a debt instrument (Garr, 2013). This can arise due to the decline in the creditworthiness of the borrower or the inability on their part to fulfil their contractual obligations (Manab et al., 2015). Lenders are concerned with the level of credit risk because it determines the extent to which they will be able to receive returns on their investment. According to Manab et al. (2015) high credit risk ratings reduces investor confidence and can lead to divestment. Whilst a huge pool of literature exists on the relationship between credit risk and its associated bank-specific and macroeconomic determinants, the impact of institutional variables on financial stability cannot be dismissed (Ashraf, 2017, Roe and Siegel, 2011). Theoretically our study is founded on theories of bank risk-taking behavior and the theory of political institutions. Ashraf (2017) provides a theoretical link between bank risk-taking and political institutions in which political stability encourages high risk-taking by banks, and hence increases financial instability. According to Acemoglu and Robinson (2010) institutions can be divided into political and economic institutions. Whilst the former is equally important for the attainment of increased welfare, the latter is argued to be directly related to economic activity. Economic

\footnotetext{
${ }^{1}$ South Africa experienced several credit rating downgrades during the period 2012 to 2017, during the Presidency
} of Jacob Zuma. 
institutions such as financial regulation, other laws and investor protection rules are essential in promoting financial market activity (Qi et al., 2010, Roe and Siegel, 2011).

Roe and Siegel (2011) argue that political institutions impact the financial sector through their effect on economic institutions. In another study, Liu and Zhong (2017) find that political uncertainty impact more on credit risk of firms where investor protection is low. This view suggests that it is difficult to maintain sound economic institutions in the absence of a robust political system. The present study tests both theories and provides evidence of the effect of political institutions on credit risk in both the short-run and long-run. Other stylized determinants of credit risk have been divided into macroeconomic, industry and firm-specific determinants (Manab et al., 2015, Podpiera and Ötker, 2010, Virolainen, 2003). Knoop (2008) argues that interest in the analysis of credit risk stems from the importance attached to the financial sector in achieving economic stability. It is therefore not surprising that recent studies have concentrated on the relationship between financial variables and the real economy. Due to data constraints however, fewer studies have been carried out in the sub-Saharan region (Garr, 2013, Nikolaidou and Vogiazas, 2017). The bulk of the studies have concentrated on advanced economies, which generally have large financial sectors (Chaibi and Ftiti, 2015) and Asian emerging market economies (Waemustafa and Sukri, 2015).

Studies in South Africa includes Havrylchyk (2010). Clark and Kassimatis (2015) and Nikolaidou and Vogiazas (2017) also include South Africa in different panel studies. Havrylchyk (2010) identifies macroeconomic influences on credit risk in South Africa and stress tests the South African banking sector using scenario analysis. In Nikolaidou and Vogiazas (2017) macroeconomic determinants of credit risk are analyzed for five sub-Saharan countries including South Africa. Both studies do not consider the effect of political institutions on credit risk, which is one of the objectives of this paper. Clark and Kassimatis (2015) add a political risk variable in a panel of 22 countries to account for credit risk. It is however not feasible to derive any country-specific policy conclusions from panel studies. Castro (2013) segments the determinants of credit risk into systematic and unsystematic factors. Unsystematic or idiosyncratic risk factors are factors relating to individual firms, such as firm management, financial position, financing sources and production processes. Idiosyncratic factors can however be controlled by the firm, although it will depend on the firm's risk management skills.

Thus at the macro level, it is systematic risk that researchers are concerned with. Systematic risk factors are those macroeconomic and industry-wide factors that may cause a business to default on its obligations (Manab et al., 2015). According to Cosset and Roy (1991) such studies can be used to validate credit rating agencies' sovereign credit ratings. Systematic variables that have been used to explain credit risk include the gross domestic product (GDP) as a measure of overall economic activity or the size of the economy. Castro (2013) argues that the worsening of economic activity should increase credit risk as consumers are faced with a constraining environment that inhibits their debt servicing capacity. In their study GDP has a negative influence on non-performing loans. Other variables that have been used are the real effective exchange rate, the inflation rate, credit to private sector, the interest rate and government borrowing (Castro, 2013, Garr, 2013, Louzis et al., 2012, Manab et al., 2015, Liu and Zhong, 2017). We add a variable that accounts for political risk in the form of a Government Integrity (GI) ${ }^{2}$ index from Heritage's Economic freedom index.

Empirical Literature: The first step in analysing credit risk is finding an accurate measure of credit risk itself. Different measures have been suggested in the literature, including non-performing loans, loan loss provisions and sovereign credit spreads (Garr, 2013, Podpiera and Ötker, 2010). Podpiera and Ötker (2010) describe three ratios that measure the quality of bank assets, the ratio of loan loss provisions to total loans, the ratio of Non-performing loans to Total loans and the ratio of loan loss provisions to Non-performing loans. Loan loss provisions measure credit risk in the short term whilst non-performing loans could measure risk in the long term. They argue that both measures should be positively related to credit risk. The present study uses both loan loss provisions and Non-performing loans as measures of credit risk to measure the risk of default in debt extended by South African banks. Several studies have undertaken to empirically analyse

\footnotetext{
${ }^{2}$ Government Integrity Index derives from Transparency International's Corruption Perceptions Index. It is based on a scale of 0 to 10 where 0 represents high corruption and 10 represents little corruption. The measure is converted to percentage by multiplying it by a scale of 10 .
} 
the underlying sources of credit risk (Garr, 2013, Jiménez and Saurina, 2004, Waemustafa and Sukri, 2015, Castro, 2013). However constraints in the form of lack of reliable data have limited such studies in developing countries, especially Africa (Nikolaidou and Vogiazas, 2017). Available studies show that a number of factors affect credit. These can be grouped into bank level characteristics, industry level factors and macroeconomic factors.

The study by Manab et al. (2015) uses four bank ratios as independent variables in a logistic regression to determine the sources of bankruptcy among Malaysian banks. The study shows that the profitability ratio was positively related to distress. Working capital ratio is negatively related to bankruptcy. Their study points to better credit risk management at the bank level. Their findings are supported by Garr (2013) who finds a positive association between credit risk and management efficiency. Garr (2013) carried out a study on Ghana using aggregated data from 33 banks. The study employs Ordinary Least Squares regression and finds that credit risk is positively related to GDP per capita and management inefficiency. Government borrowing and financial sector development negatively influence credit risk. The relationship between GDP and credit risk is supported by Castro (2013) who investigated macroeconomic determinants of credit risk in five European countries. Castro (2013) employs panel data techniques, ranging from the pooled OLS estimator, fixed effects model, random effects model and the Arrelano and Bond GMM estimator. In another study Nikolaidou and Vogiazas (2017) use the ARDL approach to cointegration to establish the relationship between credit risk and its determinants in African countries. Their study uses different explanatory variables for five Sub-Saharan African countries to explain credit risk in Africa. Of interest is the inclusion of South Africa in this study. However, whilst macroeconomic factors are found to be of statistical significance, no reference is made to institutional factors, which underlie most macroeconomic dynamics. Money supply, gold prices and the Treasury bill rate are all found to be statistically significant.

\section{Econometric Modeling and Data}

The study uses quarterly data from the SARB and an institutional index from Heritage that measures government integrity for the period 1998 Q1 to 2016 Q4. Whilst 1994 would be the year of choice to start at as the new regime took over, the sample choice is constrained by lack of data on government integrity for periods beyond 1998. Political stability is essential to guarantee short-term financial stability and we therefore recommend policies aimed at rooting out corruption and malfunctioning of public enterprises. The baseline model follows earlier studies by Waemustafa and Sukri (2015) and Havrylchyk (2010), and is specified below:

$N P L=f(g d p$, bank size, gold prices, reer, Political institutions, interest rate $)$

$N P L_{t}=\beta_{0}+\beta_{1} G D P_{t}+\beta_{2} I N S T_{t}+\beta_{3} i_{t}+\beta_{4} R E E R_{t}+\beta_{5} S I Z E_{-} 2_{t}+\beta_{7} G O L D_{t}+\mu$

Data on political institutions is taken from Heritage. Whilst data on several variables used is found in shorter frequency, the data on political institutions is available on a yearly basis. We transform the data to quarterly frequency ${ }^{3}$. All data that is not in percentages is transformed into logarithms. This has at least two advantages; firstly, coefficients can be interpreted as elasticities. A second advantage is to avoid heteroscedasticity. Whilst growth has been sluggish in South Africa, diversification of industries and boosting the informal economy could result in higher output. Secondly we suggest that sound political institutions be accompanied by relevant regulation of financial markets for long-term financial stability.

Estimation Technique: Several techniques for estimating time series data are used in literature ranging from the single equation to techniques that can simulate a system of equations. Although most single equation techniques provide information on the relationship between a theoretically determined dependent variable and its determinants, they are limited however in cases where some variables are endogenous and where dynamic effects are important. Due to such considerations and the fact that data on NPLs is not available for a longer period of time, the study employs the ARDL technique of Pesaran and Shin (1998) as the

\footnotetext{
${ }^{3}$ A quadratic based interpolation is used in E views to transform the data. Alternative data generating processes do not suggest significant changes to our results.
} 
base modelling approach. Nkoro and Uko (2016) argue that the ARDL approach is preferred to the Vector autoregression (VAR) where a single cointegration vector exists and does not require that all variables be integrated of the same order. The ARDL approach can be applied when series are either I(0) or I(1) or a combination of both (DAVIDESCU, 2015, Nikolaidou and Vogiazas, 2017). In addition Nikolaidou and Vogiazas (2017) argue the ARDL approach is robust to small samples. Single equation estimation in the form of the Fully Modified OLS will be estimated to check whether the results are robust to a change in the estimation technique. The ARDL model for the present study can be expressed as follows:

$\Delta N P L_{t}=\alpha_{0}+\sum_{i=1}^{n} \alpha_{1 i} \Delta N P L_{t-1}+\sum_{i=1}^{n} \alpha_{2 i} \Delta R E E R_{t-1}+\sum_{i=1}^{n} \alpha_{3 i} \Delta L G D P_{t-1}+\sum_{i=1}^{n} \alpha_{4 i} \Delta L G O L D_{t-1}+$ $\sum_{i=1}^{n} \alpha_{5 i} \Delta G I_{t-1}+\sum_{i=1}^{n} \alpha_{6 i} \Delta S I Z E_{-} 2_{t-1}+\alpha_{7} N P L_{t-1}+\alpha_{8} R E E R_{t-1}+\alpha_{9} L G D P_{t-1}+\alpha_{10} L G O L D_{t-1}+\alpha_{11} G I_{t-1}+$ $\alpha_{12} S I Z E_{-} 2_{t-1}+\alpha_{13} \operatorname{CRISIS}_{t}+\epsilon_{t}$

Where $\alpha_{1}-\alpha_{6}$ are the short-run coefficients and $\alpha_{7}-\alpha_{13}$ NPL is the ratio of non-performing loans to total loans and advances of banks. The data is collected from the South African Reserve Bank ${ }^{4}$. REER represents the real effective exchange rate and LGDP is the log of GDP at market prices. Government integrity (GI) is a measure of political institutions, taken from Heritage.org. The data for GI originates from Transparency International corruption index, which ranges from 0 to 10 . We multiply each score buy 10 to convert it into a percentage. SIZE_2 is the ratio of loans to total assets expressed as a percentage. LGOLD is the logarithm of gold prices. Since South Africa is a major exporter of gold, we expect that an increase in gold prices should reduce credit risk. CRISIS is a dummy that accounts for the $2007 / 2008 \mathrm{GFC}$.

Unit Roots Tests: The data is tested for unit roots using the Augmented Dickey-Fuller (ADF) test and the Philips Perron test (PP). Testing for unit roots has become a standard practice in the analysis of time series data as it allows the researcher to establish the order of integration of a series. However, the aim of unit root tests in the ARDL model is not to determine if the variables are integrated of the same order but to ensure that no variables are integrated of order 2 (I2) and above. As a result of the longer period under analysis, the data may contain structural breaks, especially to reflect the Global Financial Crisis (GFC). Under such conditions, the ADF and PP tests do not have the power to reject the null hypothesis of no unit root. A structural break unit test is used as a robustness check.

Lag Length Selection Criteria: Brooks (2014), identifies two ways of selecting the optimal lag length. Firstly, the use of data frequency is a widely acknowledged method of selecting a lag length. The approach assigns a lag length of 1 for annual data, a lag length of 4 for quarterly data, and a lag length of 12 for monthly data. The second approach is the VAR lag length selection criterion, which utilizes various criterions to establish the lag length. The criterion used in the VAR approach include the Final prediction error (FPE), Akaike Information Criterion (AIC), the Hannan Quin (HQ), the Schwarz Bayesian Criterion (SBC) and the LR ratio. The study uses the VAR, which is run in differences to determine the lag length. Using the LR ratio, the number of lags chosen is four. However, when estimating the equation in $\mathrm{E}$ views, we find it appropriate to use a maximum of 3 lags and allow for automatic selection of lags for each variable.

Bounds Test to Cointegration: Before one can estimate the short-run and long-run coefficients of the model, the ARDL approach requires that one estimate the equation in levels and use of the Pesaran et al. (2001) Bounds test approach to test for cointegration. Nkoro and Uko (2016) show that the Bounds test for cointegration uses a Wald-type, F-test to test the joint significance of coefficients in the above-specified model, separately for the long-run and short-run sections. If the F-statistic obtained is greater than the upper bound of the critical values, cointegration between the variables exists. When the F-statistic falls inside the band, then cointegration cannot be determined. Thirdly, if the F-statistic falls below the lower bound, there is no cointegration (Pesaran et al., 2001).

Long-Run and Short-Run Effects: Having established the existence of a cointegrated relationship, the next step is to estimate the Error Correction model. Of importance however is the sign of the Error correction term (ECT). When the ECT has a negative sign, with an absolute value less than one, then it can be concluded that the deviation from equilibrium is being corrected (i.e. convergence takes place). On the other hand, if the ECT is positive, there is divergence. The disequilibrium is not corrected. An ECT that is negative but greater than one in absolute terms may indicate that the model is over correcting.

\footnotetext{
${ }^{4}$ Annual Reports of the Bank Supervision Department of the SARB
} 


\section{Empirical Results}

Descriptive Statistics and Unit Root Testing: Descriptive statistics are provided in Table A1 in the appendix. Agung (2011), notes that policy analysis and decision making can be enhanced by paying attention to the uni-variate characteristics of the data. These low-interest rates could result in increased credit and if coupled with lax credit requirements, lead to high non-performing loans. Measures of central tendency such as mean, median and mode are calculated and displayed in a table for each variable. Table 1 below summarizes results of the unit root tests performed on each variable. Three unit-root tests are undertaken; augmented Dicky-Fuller test, Philips Peron test and Breakpoint unit root test. Detailed results are shown in table A3 in the appendix. No trend specification is made and all but one of the variables I (1). The remaining variable (REER) is I (0).

Table 1: Unit Root Tests

\begin{tabular}{cllll}
\hline Variable & ADF statistic & PP Statistic & $\begin{array}{l}\text { Break Test } \\
\text { statistic }\end{array}$ & Overall Decision \\
\hline NPL_1 & -1.088453 & -0.734371 & -2.968600 & Non-stationary \\
GI & -0.585186 & -1.539981 & -2.514177 & Non-stationary \\
LGOLD & 2.468720 & 3.466406 & -3.245280 & Non-stationary \\
SIZE_2 & -0.130597 & -0.154437 & -1.668569 & Non-stationary \\
REER & $-8.042978^{* * *}$ & $-8.031491^{* * *}$ & $-8.609581^{* * *}$ & Stationary \\
LGDP & 16.91130 & 14.24842 & -3.557097 & Non-stationary \\
$\Delta N P L \_1$ & $-2.616399^{* * *}$ & $-4.007213^{* * *}$ & $-2.214896^{* *}$ & Stationary \\
$\Delta G I$ & $-4.222026^{* * *}$ & $-4.831735^{* * *}$ & $-5.141911^{* * *}$ & Stationary \\
$\Delta L G O L D$ & $-6.215590^{* * *}$ & $-6.209132^{* * *}$ & $-7.612380^{* * *}$ & Stationary \\
$\Delta S I Z E \_2$ & $-7.922491^{* * *}$ & $-8.043682^{* * *}$ & $-8.761511^{* * *}$ & Stationary \\
$\Delta L G D P$ & -1.162702 & $-2.248192^{* *}$ & $-80782132^{* * *}$ & Stationary \\
\hline
\end{tabular}

$* * *, * *, *$ indicates stationary at $1 \%, 5 \%$ and $10 \%$ levels respectively $\Delta$ indicates the first difference

Model Selection and Lag Length Selection: The final model selected using the Akaike Information Criterion (AIC) is $(3,1,1,2,0,1)$ as shown in Figure 1 below. The highest lag for both the dependent and independent variables is set at 3 and we use the automatic lag selection option. Initially we follow the traditional VAR lag length selection criterion by running a VAR in differences for all save for one of the variables that is I (0). We choose 4 lags as selected by the LR ratio. During estimation however, we adjust the lags to get rid of serial correlation problem. The criterion for model selection is that we select the model with the lowest AIC value.

Figure 1: Model Selection

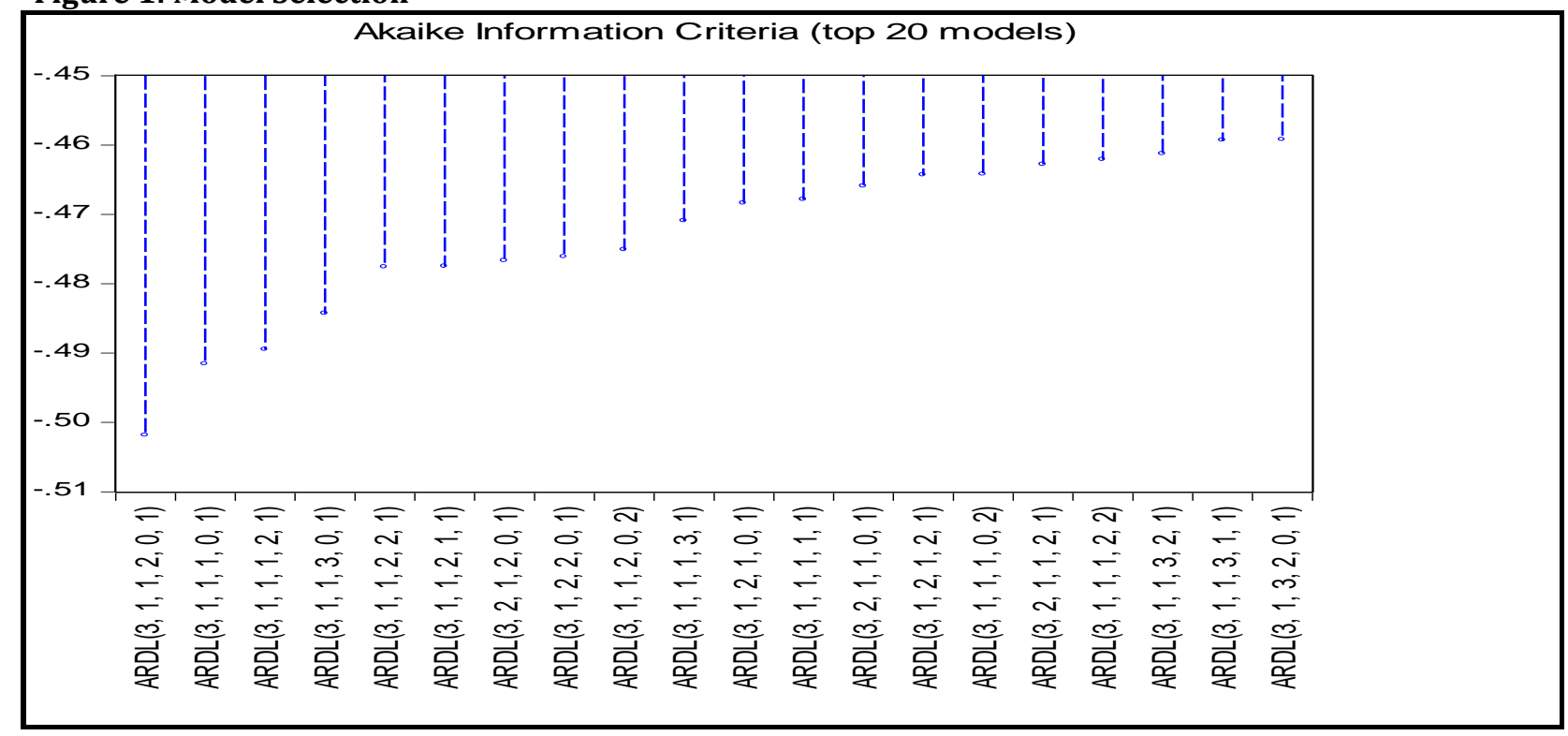


Model Diagnostics and Stability Tests: Two of our coefficients signs require special mention because they differ from theoretical expectations. Firstly, gold prices show a positive and significant relationship with nonperforming loans. In the long run a 1\% increase in gold prices results in a 1.93\% increase in non-performing loans. The result differs from Nikolaidou and Vogiazas (2017) and Havrylchyk (2010). The same result is found in Dimitrios et al. (2016) and Castro (2013). This could be indicating the increase in credit taken by gold producers in order to sustain large trade volumes as prices are increasing (Gillespie et al., 2010). The selected model meets the criterion as determined by a test for serial correlation and heteroscedasticity. As shown in table A3 in the appendix both the F-statistic and the observed R-squared test statistics are not statistically significant, implying that we cannot reject the null hypothesis of no serial correlation. Table A4 shows the results from the Breusch-Pagan-Godfrey test for heteroscedasticity. We employ the Ramsey RESET test in table A5 to test whether the model is correctly specified and the results show that the model is correctly specified. Further we also use the CUSUM test as shown in Figure A1 to test model coefficients stability. The model selected is also dynamically stable as shown by the AR roots graph below.

\section{Figure 2: Model Dynamic Stability}

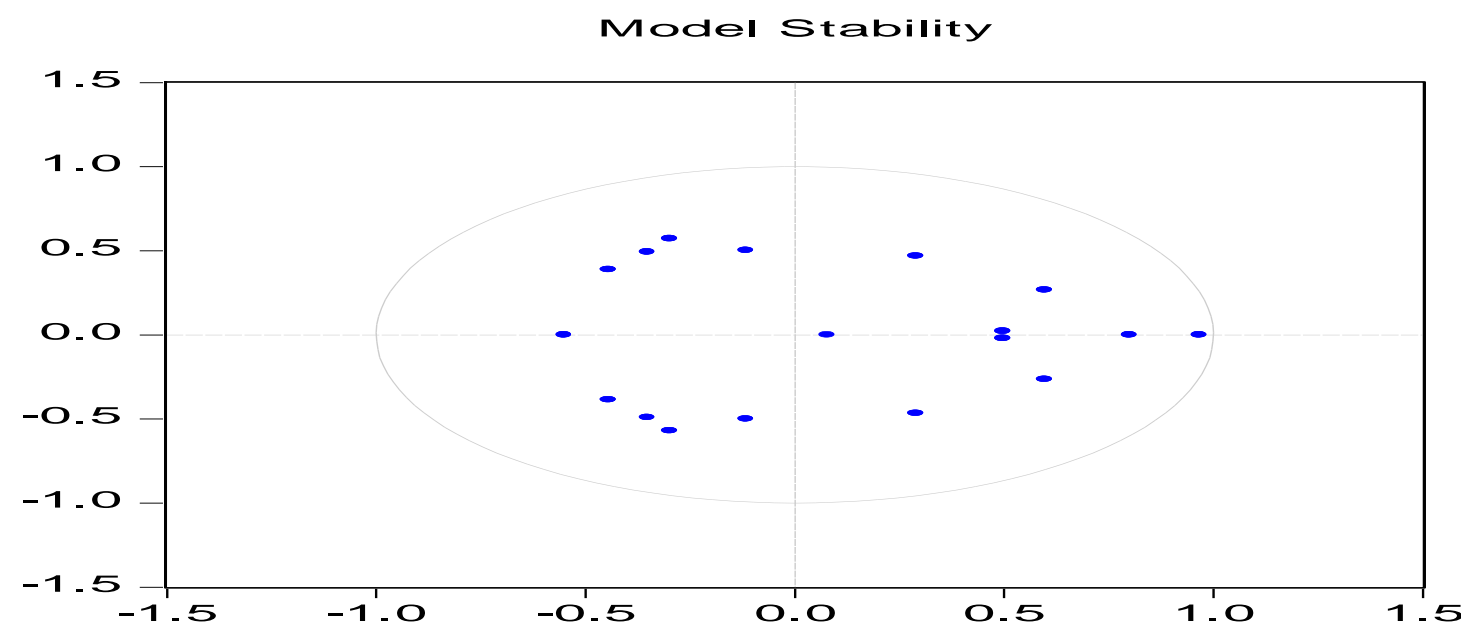

Bound Test Results: Cointegration results are shown in Table 2 below as shown in the table, the F-statistic of 3.63 is greater than the upper bound at $5 \%$ level of significance. Therefore, we can conclude that the variables in the model are cointegrated and a long-run relationship exists. The result resonates with existing evidence from studies such as Nikolaidou and Vogiazas (2017). This finding necessitates the use of the ARDL technique to estimate both short-run and long-run coefficients.

Table 2: Bounds Test for Cointegration

\begin{tabular}{llll}
\hline & F-statistic & \multicolumn{2}{c}{ Critical bounds at 5\% } \\
& & Lower bound I(0) & Upper bound I(1) \\
\hline Model 1 & 3.63 & 2.14 & 3.34 \\
\hline
\end{tabular}

\section{Estimation Results and Discussion}

Long-Run: Long-run estimates are shown in Table 3 below. As expected GDP and credit risk have a negative and significant relationship at the $1 \%$ level of significance. Specifically, a $1 \%$ increase in GDP results in a $1.88 \%$ decrease in non-performing loans. This is not surprising as an increase in economic activity should increase households and firm income, which in turn improves their capacity to repay loans. The coefficient of the size of the banking system as measured by total bank assets is positive at 0.24 and significant at $10 \%$ level. Non-performing loans are increasing as banks expand their operations. The REER does not significantly influence credit risk in the long-run. The dummy representing the 2007/8 crisis shows a positive and significant relationship between credit risk and the crisis. This is expected as the crisis had a negative impact on economic activity and employment leading to reduced income levels. The resultant recession decreased the capacity of borrowers to service their debt and increased the balance of overdue loans on the bank's 
balance sheets. Thus as commodity buyers increase purchases, credit purchases also increase and defaulters increase, cutting on cash receipts of gold producers who turn to bank credit to sustain supply.

In turn commodity producers also default on their bank obligations, increasing NPLs in the process. Government integrity (GI) is negatively related to credit risk in the short run as expected from theory. These short-run results justify credit rating downgrades assigned to South Africa in recent years due to inconsistency in policy characterized by a change of government ministers and corruption allegations against senior government officials. Increased corruption erodes consumer and business confidence in the economy resulting in low economic activity and reduced ability to repay debt. On the contrary, it is however showing a positive and significant relationship with credit risk in the long-run. This implies political stability could be contributing to lax borrowing requirements by lenders, creating periods of stability in which credit extension is negligently done. Another reason stems from the literature on bank risk-taking behavior. As shown in Ashraf (2017) political stability encourage high risk-taking by banks, especially where competition from nonbank financial institutions is rife in loan offerings. Qi et al. (2010) demonstrate that political institutions have an important effect on the interest rate, with increased political rights resulting in low-interest rates.

Table 3: Long Run Coefficients

\begin{tabular}{lllc}
\hline Sample: 1998Q1 2016Q4 Dependent variable: NPL_1 & & \\
\hline Variable & Coefficient & t-statistic & P-value \\
\hline REER & 0.018806 & 0.3043 & 0.7668 \\
LGDP & $-1.876089^{* * *}$ & -3.1632 & 0.0025 \\
LGOLD & $1.931302^{* * *}$ & 2.7564 & 0.0078 \\
GI & $0.248310^{* * *}$ & 3.4605 & 0.0010 \\
SIZE_2 & $0.126198^{*}$ & 1.7875 & 0.0790 \\
CRISIS & $4.283761^{* *}$ & 2.5526 & 0.0133 \\
\hline
\end{tabular}

***, ${ }^{* *}$ and $*$ denote $1 \%, 5 \%$ and $10 \%$ level of significance respectively

Short-Run Results: In the short-run as evident from table 5, the error correction term is negative and highly significant at $1 \%$ level. The short-run dynamics are therefore reinforcing the model towards equilibrium in the long-run. The ECT of -0.11 implies that about $11 \%$ of the deviation from equilibrium in the previous quarter is corrected in the current quarter. The speed of adjustment is fair considering that the data is of quarterly frequency, which is relatively high. The coefficients of GDP, GI, SIZE_2 and CRISIS are all highly significant and take the expected signs. GDP is negatively related to non-performing loans. Government integrity is negatively related to non-performing loans, which may confirm the negative influence on financial stability witnessed in recent years. This finding resonates with the decision by rate agencies to downgrade South African bonds in recent years and confirms results by other studies (Havrylchyk, 2010). As captured by the size of banking assets, industry factors play a more pronounced role in determining credit risk in the short-run. SIZE_2 is highly significant at $1 \%$ level in the short-run with a positive coefficient of 0.10 . Again we do find a paradox as gold prices reflect a positive and highly significant influence on non-performing loans in the short-run. We report that a $1 \%$ increase in gold prices results in a $1.3 \%$ increase in non-performing loans (worsening of credit risk).

Table 4: Cointegrating Form

Sample: 1998Q1 2016Q4 Dependent Variable: NPL_1

\begin{tabular}{lllc}
\hline Variable & Coefficient & t-statistic & P-value \\
\hline D (NPL_1 (-1)) & $0.320704^{* * *}$ & 3.01308 & 0.0038 \\
D (NPL_1 (-2)) & $0.260869^{* *}$ & 2.40275 & 0.0195 \\
D (REER) & 0.002044 & 0.3085 & 0.7588 \\
D (LGDP) & $-4.649577^{* *}$ & -2.2746 & 0.0266 \\
D (LGOLD) & $1.285868^{* * *}$ & 2.8398 & 0.0062 \\
D (GI) & $-0.065215^{* *}$ & -2.1634 & 0.0346 \\
D (SIZE_2) & $0.103445^{* * *}$ & 2.9765 & 0.0042 \\
D (SIZE_2 (-1)) & 0.052304 & 1.4970 & 0.1398 \\
D (CRISIS) & $0.465499^{* * *}$ & 3.4805 & 0.0010
\end{tabular}




\begin{tabular}{lcc} 
CointEq $(-1)$ & $-0.108666 * * *$ & -3.9219 \\
Cointeq $=$ NPL_1 - & $(0.0188 *$ REER-1.8761*LGDP $+1.9313 *$ LGOLD $+0.2483 * G I+0.1262 *$ SIZE_2 + \\
$4.2838 *$ CRISIS $)$ & \\
\hline$* * * *$ and $*$ denote $1 \%, 5 \%$ and $10 \%$ level of significance respectively
\end{tabular}

\section{Conclusion and Policy Recommendations}

The study investigates the macroeconomic and institutional determinants of credit risk. We use the gross domestic product, gold prices, the real effective exchange rate, government integrity and the size of the banking sector as determinants of credit risk in South Africa. Our measure of credit risk is non-performing loans. The gross domestic product has a negative influence on credit risk both in the short-run and in the long-run. The results are in line with findings from similar studies by Dimitrios et al. (2016) and Castro (2013). These results have strong implications for the role of increased economic activity in driving down the number of non-performing loans. However, these findings are unique in that they provide representations for both the short-run and long-run periods. We find that government integrity is negatively related to credit risk in the short-run but positively related to credit risk in the long-run. The short-run results resonate with a theory on political risk and credit (Liu and Zhong, 2017). Thus as argued in Knoop (2008), our results show that credit markets are important in driving the business cycle. Increased credit risk induces investors to withdraw funding or seek safe investments elsewhere.

Contrary to the preceding, we do not find evidence that government integrity is important in improving credit risk in the long-run. Instead, an improvement in government integrity seems to be exacerbating credit risk in the long-run. This finding is in line with theories of bank risk-taking behaviour and implies South African banks face stiffer competition in credit markets during periods of political stability, hence engage in high-risk lending to beat completion (Ashraf, 2017). Our results also find a positive relationship between nonperforming loans and gold prices in both the short and long-run, which is contrary to the findings of Nikolaidou and Vogiazas (2017). Other studies linking gold prices to the financial sector do not find a statistically significant relationship between the two (Ziaei, 2012). The ratio of loans to total banking assets is positively related to credit risk in both the short-run and the long-run. The positive sign on SIZE_2 shows that growth in bank assets increases the vulnerability of the banking industry. The result support evidence by Nikolaidou and Vogiazas (2017) who uses the loan to asset ratio to determine the effect of the growth in loans on credit risk. In the spirit of this paper, we recommend policies that are aimed at increasing economic growth.

\section{References}

Acemoglu, D. \& Robinson, J. (2010). The role of institutions in growth and development. Leadership and growth, 135.

Agung, I. G. N. (2011). Time series data analysis using EViews, John Wiley \& Sons.

Ashraf, B. N. (2017). Political institutions and bank risk-taking behavior. Journal of Financial Stability, 29, 1335.

Ayadi, F. S. \& Ayadi, F. O. (2008). The impact of external debt on economic growth: A comparative study of Nigeria and South Africa. Journal of Sustainable Development in Africa, 10, 234-264.

Brooks, C. (2014). Introductory econometrics for finance, Cambridge university press.

Castro, V. (2013). Macroeconomic determinants of the credit risk in the banking system: The case of the GIPSI. Economic Modelling, 31, 672-683.

Chaibi, H. \& Ftiti, Z. (2015). Credit risk determinants: Evidence from a cross-country study. Research in international business and finance, 33, 1-16.

Chang, C., Fuh, C. D. \& Kao, C. L. M. (2017). Reading between the ratings: Modeling residual credit risk and yield overlap. Journal of Banking \& Finance, 81, 114-135.

Clark, E. \& Kassimatis, K. (2015). Macroeconomic effects on emerging-markets sovereign credit spreads. Journal of Financial Stability, 20, 1-13.

Cosset, J. C. \& Roy, J. (1991). The determinants of country risk ratings. Journal of International Business Studies, 135-142. 
Davidescu, A. A. (2015). Bounds test approach for the long run relationship between the shadow economy and official economy. An empirical analysis for Romania. Journal of applied quantitative Methods, 10.

Dimitrios, A., Helen, L. \& Mike, T. (2016). Determinants of non-performing loans: Evidence from Euro-area countries. Finance research letters, 18, 116-119.

Garr, D. K. (2013). Determinants of credit risk in the banking industry of Ghana. Developing Country Studies, 3 , 2225-0565.

Gillespie, B., Hackwood, J. \& Mihos, C. (2010). Managing credit risk for global commodity producers. Australia: PricewaterhouseCoopers.

Havrylchyk, O. (2010). A macroeconomic credit risk model for stress testing the South African banking sector. Working Paper, WP/10/02.

Jiménez, G. \& Saurina, J. (2004). Collateral, type of lender and relationship banking as determinants of credit risk. Journal of Banking \& Finance, 28, 2191-2212.

Knoop, T. A. (2008). Modern financial macroeconomics: panics, crashes, and crises, Wiley-Blackwell.

Liu, J. \& Zhong, R. (2017). Political uncertainty and a firm's credit risk: Evidence from the international CDS market. Journal of Financial Stability, 30, 53-66.

Louzis, D. P., Vouldis, A. T. \& Metaxas, V. L. (2012). Macroeconomic and bank-specific determinants of nonperforming loans in Greece: A comparative study of mortgage, business and consumer loan portfolios. Journal of Banking \& Finance, 36, 1012-1027.

Manab, N. A., Theng, N. Y. \& Md-Rus, R. (2015). The Determinants of Credit Risk in Malaysia. Procedia-Social and Behavioral Sciences, 172, 301-308.

Nikolaidou, E. \& Vogiazas, S. (2017). Credit risk determinants in Sub-Saharan banking systems: Evidence from five countries and lessons learnt from Central East and South East European countries. Review of Development Finance, 7, 52-63.

Nkoro, E. \& Uko, A. K. (2016). Autoregressive Distributed Lag (ARDL) cointegration technique: application and interpretation. Journal of Statistical and Econometric Methods, 5, 63-91.

Pesaran, M. H. \& Shin, Y. (1998). An autoregressive distributed lag modelling approach to cointegration analysis. Econometric Society Monographs, 31, 371-413.

Pesaran, M. H., Shin, Y. \& Smith, R. J. (2001). Bounds testing approaches to the analysis of level relationships. Journal of Applied Econometrics, 16, 289-326.

Podpiera, J. \& Ötker, M. I. (2010). The fundamental determinants of credit default risk for European large complex financial institutions, International Monetary Fund.

Qi, Y., Roth, L. \& Wald, J. K. (2010). Political rights and the cost of debt. Journal of Financial Economics, 95, 202226.

Roe, M. J. \& Siegel, J. I. (2011). Political instability: Effects on financial development, roots in the severity of economic inequality. Journal of Comparative Economics, 39, 279-309.

Virolainen, K. (2003). Macro stress testing with a macroeconomic credit risk model for Finland. Bank of Finland.

Waemustafa, W. \& Sukri, S. (2015). Bank specific and macroeconomics dynamic determinants of credit risk in Islamic banks and conventional banks. International Journal of Economics and Financial Issues, 5.

Ziaei, S. M. (2012). Effects of gold price on equity, bond and domestic credit: Evidence from ASEAN+ 3. Procedia-Social and Behavioral Sciences, 40, 341-346.

\section{Appendix}

Table A1: Correlation Analysis

\begin{tabular}{llllllll}
\hline & NPL_1 & LGOLD & LGDP & REER & GI & CRISIS & SIZE_2 \\
\hline NPL_1 & 1,0000 & & & & & & \\
LGOLD & 0.2293295 & 1,0000 & & & & \\
LGDP & 0.1128877 & 0.9797495 & 1,0000 & & & \\
REER & 0.0549836 & -0.006428 & 0.0394582 & 1,0000 & & \\
GI & 0.3104460 & -0.690214 & -0.764350 & 0.03302881 & 1,0000 & & \\
CRISIS & 0.1496169 & 0.1104588 & 0.0981323 & 0.12248471 & 0.0879167 & 1,0000 &
\end{tabular}


$\begin{array}{llllllll}\text { SIZE_2 } & 0.2975786 & -0.184045 & -0.279218 & -0.0816926 & 0.2157096 & -0.239511 & 1,0000\end{array}$

*GDP and Gold prices appear highly correlated - could lead to the problem of multi-collinearity. But as argued in Madala and Lahiri (2009) highly cross correlation alone is not enough to conclude the presents of multicollinearity.

Table A2: Descriptive Statistics

\begin{tabular}{llllllll}
\hline & NPL_1 & LGOLD & LGDP & LSIZE & REER & GI & CRISIS \\
\hline Mean & 3.450921 & 8.581133 & 14.48843 & 14.49658 & -0.140789 & 47.18947 & 0.052632 \\
Median & 3.390000 & 8.470188 & 14.54233 & 14.65904 & 0.700000 & 47.18750 & 0.000000 \\
Maximum & 5.940000 & 9.846258 & 15.29965 & 15.39907 & 13.50000 & 61.59375 & 1.000000 \\
Minimum & 1.100000 & 7.283874 & 13.53097 & 13.23998 & -15.20000 & 40.50625 & 0.000000 \\
Std. Dev. & 1.366326 & 0.817003 & 0.545825 & 0.661665 & 5.212400 & 4.042852 & 0.224781 \\
Skewness & 0.041803 & 0.020947 & -0.191459 & -0.368113 & -0.417570 & 0.689012 & 4.006938 \\
Kurtosis & 2.252180 & 1.505907 & 1.737264 & 1.765762 & 3.822847 & 4.110110 & 17.05556 \\
& & & & & & & \\
Jarque-Bera & 1.793044 & 7.074551 & 5.513569 & 6.540343 & 4.352693 & 9.915771 & 828.9727 \\
Probability & 0.407986 & 0.029092 & 0.063496 & 0.038000 & 0.113455 & 0.007028 & 0.000000 \\
& & & & & & & \\
Sum & 262.2700 & 652.1661 & 1101.121 & 1101.740 & -10.70000 & 3586.400 & 4.000000 \\
Sum Sq. Dev. & 140.0134 & 50.06201 & 22.34438 & 32.83509 & 2037.684 & 1225.849 & 3.789474 \\
Observations & 76 & 76 & 76 & 76 & 76 & & 76 \\
\hline
\end{tabular}

Table A3: Test for Serial Correlation

Breusch-Godfrey Serial Correlation LM Test:

\begin{tabular}{llll}
\hline \hline F-statistic & 1.595887 & Prob. F(2,57) & 0.2117 \\
Obs*R-squared & 3.870951 & Prob. Chi-Square(2) & 0.1444
\end{tabular}

Table A4: Test for Heteroskedasticity

Heteroskedasticity Test: Breusch-Pagan-Godfrey

\begin{tabular}{llll}
\hline \hline F-statistic & 0.854982 & Prob. F(14,58) & 0.6090 \\
Obs*R-squared & 12.48813 & Prob. Chi-Square(14) & 0.5672 \\
Scaled explained SS & 7.046238 & Prob. Chi-Square(14) & 0.9329
\end{tabular}

\section{Coefficient Stability Tests}

Table A5: Ramsey Reset Test

Omitted Variables: Squares of fitted values

\begin{tabular}{llll} 
& Value & Df & Probability \\
\hline t-statistic & 0.402062 & 58 & 0.6891 \\
F-statistic & 0.161654 & $(1,58)$ & 0.6891 \\
\hline \hline
\end{tabular}




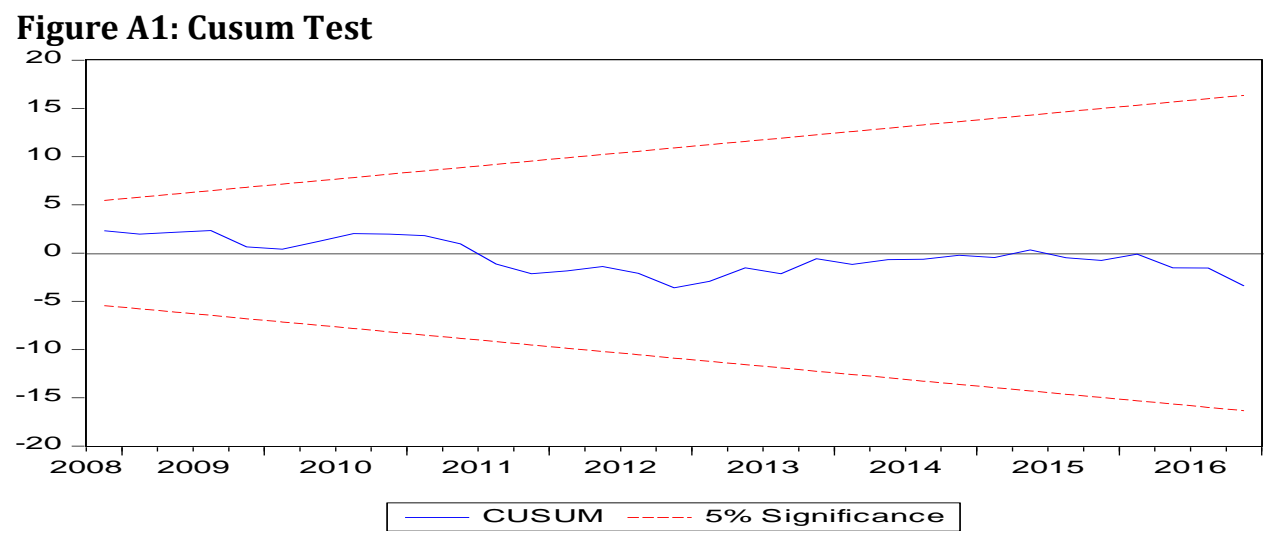

Figure A2: Residual Normality Test

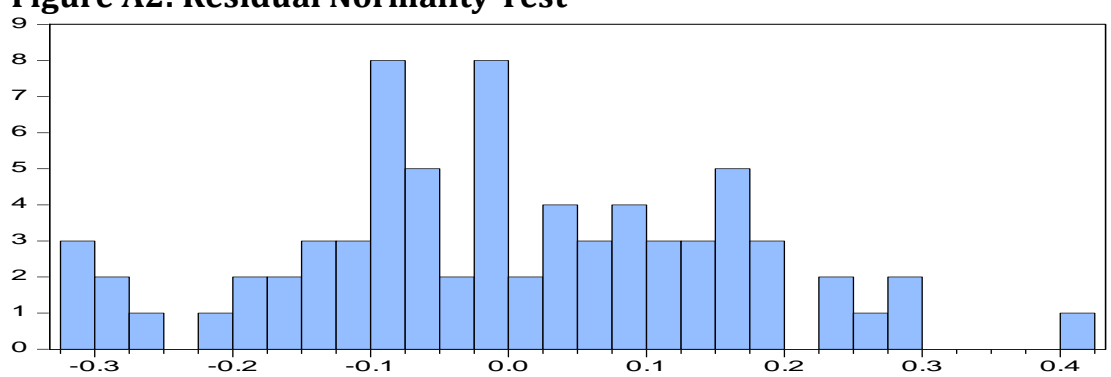

Series: Residuals Sample 1998Q4 2016Q4 Observations 73

Mean

Median

Maximum

Minimum

Std. Dev.

Skewness
Kurtosis

Jarque-Bera

Probability
$1.73 e-05$ $-0.007156$

O.411803

0.156492

0.053451

2.727530

0.260573 